\title{
Total Synthesis of Aburatubolactam $\mathbf{A}^{* *}$
}

\author{
James A. Henderson and \\ Department of Chemistry and Biochemistry University of Colorado Boulder, CO 80309-0215, USA \\ Andrew J. Phillips \\ Department of Chemistry and Biochemistry University of Colorado Boulder, CO 80309-0215, USA \\ Fax: (+)1 3034920439 Andrew.Phillips@colorado.edu
}

\section{Keywords}

natural products; metathesis; cross-coupling

\begin{abstract}
Recently Uemura and co-workers described the structure of aburatubolactam A (1, Figure 1), a macrolactam isolated from the culture broth of a Streptomyces sp. bacterium, SCRC-A20, that was separated from a marine mollusk collected near Aburatubo, Kanagawa Prefecture, Japan.[1a] Aburatubolactam A is a member of a growing class of tetramic acid-containing macrolactams including cylindramide $\mathrm{A},[1 \mathrm{~b}]$ geodin $\mathrm{A},[1 \mathrm{c}]$ xanthobaccin $\mathrm{A},[1 \mathrm{~d}]$ ikarugamycin,[1e] discodermide,[1f] and the alteramides.[1g] These mixed polyketide-amino acid metabolites have been isolated from a number of sources including sponges, marine bacteria and terrestrial bacteria,[2] and display a diverse range of biological activities including cytotoxicity, anti-microbial activity, and inhibition of superoxide generation. In this Communication we describe a synthesis of aburatubolactam A.
\end{abstract}

Our strategy for the synthesis of aburatubolactam A is based on the coupling of two domains: a subunit containing the bicyclo[3.3.0]octane (2), and a 3-hydroxyornithine-derived subunit (3, Figure 1). The bicyclo[3.3.0] octane ring system was ultimately envisioned to arise from a ring-opening—ring-closing metathesis of functionalized bicyclo[2.2.1] heptene 4. [3,4]

The synthesis commenced with a Diels-Alder reaction of commercially available ketone 6 with cyclopentadiene in the presence of $20 \mathrm{~mol} \%$ of MacMillan's catalyst 8 to give ketone $\mathbf{7}$ in $65 \%$ yield (endo:exo $>98: 2,93 \%$ ee, Scheme 1).[5] Conversion to the enone $\mathbf{4}$ was readily achieved in $80 \%$ yield by Saegusa oxidation of the trimethylsilyl enol ether derived from 7.[6] When enone 4 was subjected to 2.5 mol\% of Grubbs' catalyst 9 under an ethylene atmosphere, rapid and smooth reorganization to the desired bicyclo[3.3.0]octene 5 occurred in $90 \%$ yield.[7]

Further elaboration of 5 was accomplished by reduction of both alkenes $\left(\mathrm{Pd} / \mathrm{C}, \mathrm{H}_{2}\right)$ to give fused bicyclic ketone 10 in 94\% yield (Scheme 2). Introduction of the $\mathrm{C} 6$ and $\mathrm{C} 13$ side chains was achieved by a sequence beginning with enolate acylation with Mander's reagent,[8] followed by reduction of the ketone with $\mathrm{NaBH}_{4}$. Elimination of the resultant alcohol by mesylation and treatment with sodium hydride in $\mathrm{MeOH}$-THF (5:1) provided 11 in $64 \%$ overall yield from 10. The $\mathrm{C} 13$ side chain was introduced by employing Majetich's fluoride-mediated Sakurai allylation ${ }^{9}$ in DMF-DMPU to give $\mathbf{1 2}$ in $\mathbf{7 8 \%}$ yield as a 4:1 mixture of inseparable C6 diastereomers favoring the undesired stereochemistry (viz 12a). This ratio could be improved to 2:1 in favor of the desired stereochemistry (viz 12b) by protonation of the silylketene acetal

\footnotetext{
*** This research was supported by the National Cancer Institute (NCI CA110246). We thank Professor Daisuke Uemura (Nagoya University) for providing a sample of aburatubolactam A.
} 
derived from 12a with $\mathrm{HCl}$. Subsequent iodolactonization facilitated separation of the diastereoisomers, and gave $\mathbf{1 3}$ in 58\% yield for the two steps, along with recovered 12a. This sequence also provided a mechanism for recycling material. Treatment of iodolactone $\mathbf{1 3}$ with $\mathrm{Zn}$ dust in $\mathrm{AcOH} / \mathrm{EtOH}$, followed by reduction of the acid with $\mathrm{LAH}$ provided alcohol $\mathbf{1 4}$ in $86 \%$ yield (2 steps).

Advancement of alcohol $\mathbf{1 4}$ to $\mathbf{2}$ involved cross metathesis of butene-1,4-diol derivative $\mathbf{1 6}$ catalyzed by $\mathbf{1 5}$ to give $\mathbf{1 3}$ in $95 \%$ yield (Scheme 3). Oxidation with Dess-Martin periodinane, followed by olefination with (iodomethylene)triphenylphosphorane under Stork-Zhao[10] conditions provided vinyl iodide $\mathbf{1 9}$ in $82 \%$ yield. Conversion of the iodide to the stannane by treatment with tert-BuLi in the presence of tributyltin chloride also resulted in removal of the pivalate to give alcohol 20 in $85 \%$ yield. Treatment of this alcohol with Dess-Martin periodinane and subsequent Horner-Wadsworth-Emmons reaction yielded stannyl dioxenone 2 in $60 \%$ overall yield ( 2 steps).

The synthesis of the $\beta$-hydroxyornithine subunit $\mathbf{3}$ began with Sharpless asymmetric dihydroxylation of $\alpha, \beta$-unsaturated ester $\mathbf{2 1}$ to give diol 22 in $90 \%$ yield and $>98 \%$ ee (Scheme 4). Introduction of the nitrogen was achieved by cyclic sulfite formation and opening with sodium azide. Subsequent silylation provided ether $\mathbf{2 3}$ in $80 \%$ yield over the three steps. Reduction of the azide and nosylation[11] led to $\mathbf{2 4}$ in $94 \%$ yield, and was followed by introduction of the methyl group by Mitsunobu reaction to give 25, and removal of the nosyl group with thiophenoxide provided amine $\mathbf{3}$ ( $82 \%$ from $\mathbf{2 4}$ ).

After exploring a number of unsuccessful end game strategies that paralleled those employed for cylindramide, the synthesis was completed as shown in Scheme 5.[12] Coupling of the two halves of the molecule was achieved by heating dioxenone $\mathbf{2}$ with amine $\mathbf{3}$ in toluene under reflux for 6 hours (Scheme 5). Subjection of the sensitive $\beta$-ketoamide product to Stille coupling with tert-butyl- $\beta$-iodoacrylate, followed by Lacey-Dieckmann cyclization, led to tetramic acid 26 in 50\% yield (over three steps from 2). Macrocyclization was achieved by simultaneous removal of the Boc carbamate and tert-butyl ester with TFA and treatment of the resulting compound with DEPC [ and $\mathrm{Et}_{3} \mathrm{~N}$ in DMF for 12 hours. Removal of the TBS group with HF provided aburatubolactam A in $46 \%$ yield for the 3 steps. Data for an analytical sample of synthetic aburatubolactam A obtained by semi-preparative HPLC matched that obtained for an authentic sample provided by Professor Daisuke Uemura.

In conclusion, we have described a 23 step route that leads to aburatubolactam A and that further highlights the utility of tandem metathesis reactions in a target oriented setting.

\section{Supplementary Material}

Refer to Web version on PubMed Central for supplementary material.

\section{References}

1. a Bae MA, Yamada K, Ijuin Y, Tsuji T, Yazawea K, Tomono Y, Uemura D. Heterocycl. Commun 1996;2:315. b Kanazawa S, Fusetani N, Matsunaga S. Tetrahedron Lett 1993;34:1065. c Capon RJ, Skene C, Lacey E, Gill JH, Wadsworth D, Friedel T. J. Nat. Prod 1999;62:1256. [PubMed: 10514308] d Hashidoko Y, Nakayama T, Homma Y, Tahara S. Tetrahedron Lett 1999;40:2957. e Jomon K, Kuroda Y, Ajisaka M, Sakai HJ. Antibiotics 1972;25:271. f Gunasekera SP, Gunasekera M, McCarthy P. J. Org. Chem 1991;56:4830. g Shigemori H, Bae MA, Yazawa K, Sasaki T, Kobayashi J. J. Org. Chem 1992;57:4317.

2. The true biogenetic source of the marine sponge-derived compounds has not been determined, although they are likely bacterial metabolites. 
3. While our studies were in progress, Aubé reported this transformation in the course of their elegant synthesis of the alkaloid 251F. a Wrobleski A, Sahasrabudhe K, Aubé J. J. Am. Chem. Soc 2002;124:9974. [PubMed: 12188646] ; b Wrobleski A, Sahasrabudhe K, Aubé J. J. Am. Chem. Soc 2004;126:5475. [PubMed: 15113219]

4. For other examples of tandem metathesis sequences of this general type see: a Stille JR, Santarsiero BD, Grubbs RH. J. Org. Chem 1990;55:843; b Stragies R, Blechert S. Synlett 1998:169.; c Arjona O, Csaky AG, Medel R, Plumet J. J. Org. Chem 2002;67:1380. [PubMed: 11846691] ; d Minger TL, Phillips AJ. Tetrahedron Lett 2002;43:5357.; e Hart AC, Phillips AJ. J. Am. Chem. Soc 2006;128:1094. [PubMed: 16433523] ; f Phillips AJ, Hart AC, Henderson JA. Tetrahedron Lett 2006;47:3743.; g Chandler CL, Phillips AJ. Org. Lett 2005;7:3493. [PubMed: 16048325] ; h Pfeiffer MWB, Phillips AJ. J. Am. Chem. Soc 2005;127:5334. [PubMed: 15826167]

5. Northrup AB, MacMillan DWC. J. Am. Chem. Soc 2002;124:2458. [PubMed: 11890793]

6. Ito Y, Saegusa T. J. Org. Chem 1978;43:1011.

7. In the absence of an ethylene atmosphere the reaction proceeds in $41 \%$ yield (reflux, $12 \mathrm{~h}$ ). The presence of added $\mathrm{Ti}(i \text {-PrO })_{4}$ also failed to appreciably affect the yield of reactions run in the absence of ethylene (46\%, reflux, 12 h). For the original report of this additive see: Fürstner A, Langemann K. J. Am. Chem. Soc 1997;119:9130.

8. a Mander LN, Sethi SP. Tetrahedron Lett 1983;24:5425. b Crabtree SR, Chu WLA, Mander LN. Synlett 1990:169.

9. Majetich G, Casares A, Chapman D, Behnke M. J. Org. Chem 1986;51:1745. Although the original procedure calls for the use of HMPA, we find DMPU to be a suitable alternative.

10. Stork G, Zhao K. Tetrahedron Lett 1989;30:2173.

11. Fukuyama T, Jow C-K, Cheung M. Tetrahedron Lett 1995;36:6373.

12. A detailed account of these efforts will be forthcoming.

13. Yamada S, Kasai Y, Shioiri T. Tetrahedron Lett 1973;14:1595. 


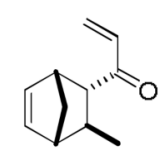

4

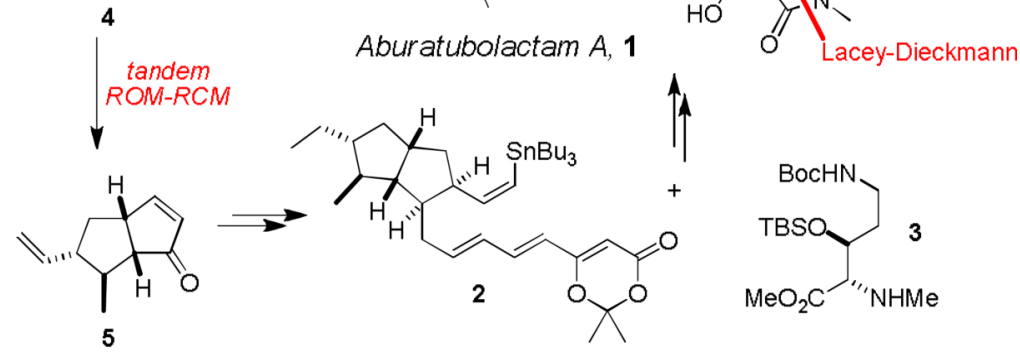

Figure 1.

Structure of Aburatubolactam A (1) and synthesis strategy. 
<smiles>C/C=C/C(=O)CC</smiles>

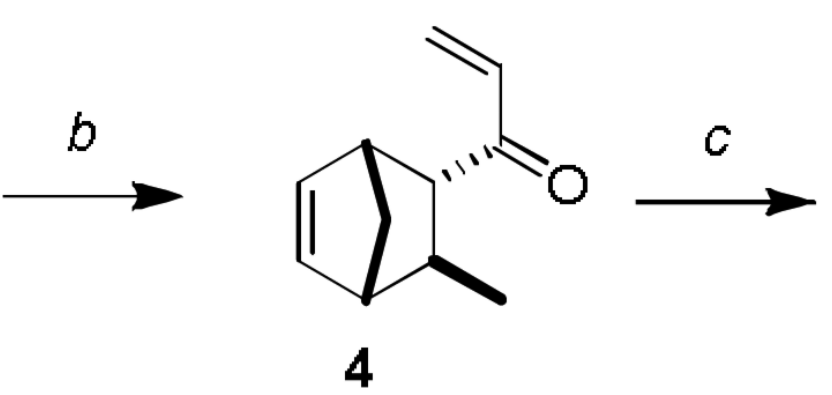

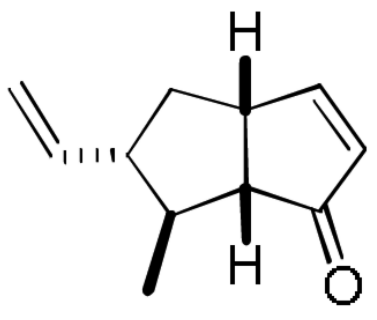

5
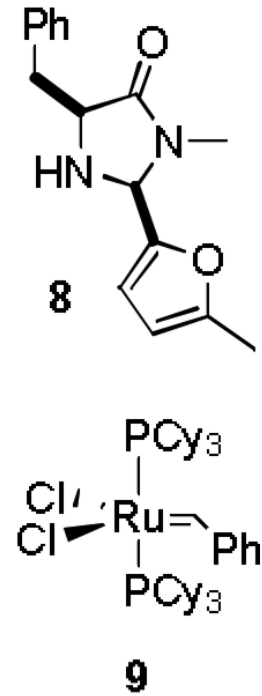

Scheme 1.

Synthesis of the bicyclo[3.3.0]octene. a) $20 \mathrm{~mol} \% \mathbf{8}, \mathrm{H}_{2} \mathrm{O}, 65 \%$; b) LiHMDS, TMSCl, THF then $\mathrm{Pd}(\mathrm{OAc})_{2}, \mathrm{MeCN}, 80 \%$; c) $2.5 \%$ 9, $\mathrm{CH}_{2}=\mathrm{CH}_{2}$ (1 atm), $\mathrm{CH}_{2} \mathrm{Cl}_{2}, 90 \%$.

LiHMDS=lithiumhexamethyl disilazide, TMS=trimethylsilyl. 
5
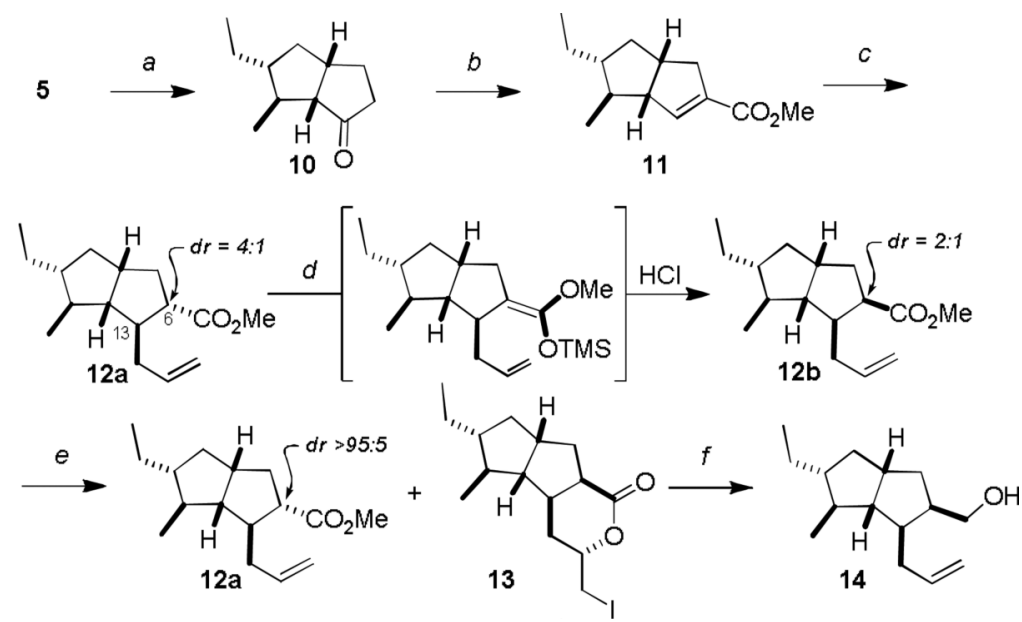

Scheme 2.

Elaboration of the bicyclo[3.3.0]octene. a) 10\% Pd/C, EtOAc, $\mathrm{H}_{2}$ (balloon), 94\%; b) 1. LDA, $\mathrm{NCCO}_{2} \mathrm{Me}$, THF-DMPU then $\mathrm{NaBH}_{4}, \mathrm{MeOH}, 74 \%$ (2 steps); 2. MsCl, DMAP, Et 3 N,

$\mathrm{CH}_{2} \mathrm{Cl}_{2}$ then $\mathrm{NaH}$, THF-MeOH, 87\% (2 steps); c) allyltrimethylsilane, TBAF, THF-DMPU, $78 \%, d r=4: 1$; d) LDA, TMSCl, THF then $1 \mathrm{~N} \mathrm{HCl}, d r=2: 1$; e) $\mathrm{I}_{2}, \mathrm{MeCN}, \mathrm{rt}, 58 \%$ (2 steps); f) $1 . \mathrm{Zn}, \mathrm{AcOH}, \mathrm{THF}-\mathrm{H}_{2} \mathrm{O} ; 2$. LAH, THF, $86 \%$ (2 steps). LDA=lithium diisopropylamide, DMPU=1,3-dimethyl-3,4,5,6-tetrahydro-2 $(1 H)$-pyrimidinone, Ms=methanesulfonyl, TBAF=tetra- $n$-butylammonium fluoride, TMS=trimethylsilyl. 
14

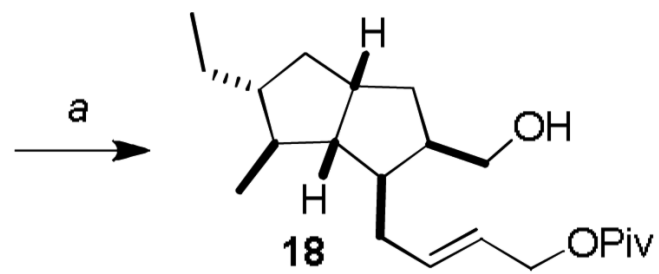

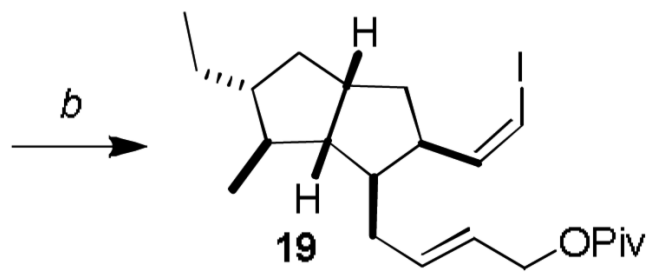<smiles>CC[C@H]1C[C@H]2C[C@H](/C=C\[Sn](C)(C)C)C(C/C=C/CO)[C@@H]([C@H]1C)[C@H]2C</smiles>
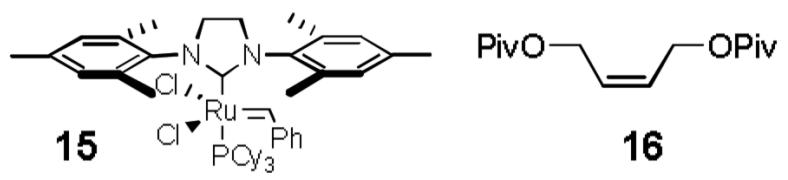

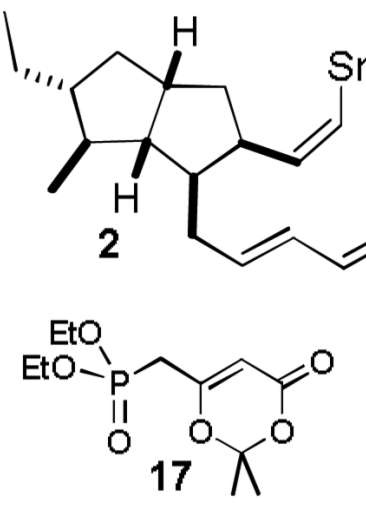<smiles>[134H]c1ccccc1</smiles>

Scheme 3.

Completion of the carbocyclic domain 2. a) 16, $10 \% \mathbf{1 5}, \mathrm{CH}_{2} \mathrm{Cl}_{2}, 95 \%$; b) 1. Dess-Martin periodinane, $\mathrm{CH}_{2} \mathrm{Cl}_{2} ; 2$. [ $\left.\mathrm{Ph}_{3} \mathrm{P}^{+} \mathrm{CH}_{2} \mathrm{I}\right] \mathrm{I}^{-}, \mathrm{NaHMDS}, \mathrm{THF}, 82 \%$ (2 steps); c) $t$ - $\mathrm{BuLi}, \mathrm{Bu} 3 \mathrm{SnCl}$ (internal quench), THF, $85 \%$; d) 1. Dess-Martin periodinane, $\mathrm{CH}_{2} \mathrm{Cl}_{2} ; 2.17$, KHMDS, THF, $60 \%$ (2 steps). KHMDS=potassium hexamethyldisilazide, $\mathrm{NaHMDS}=$ sodium hexamethyldisilazide. 


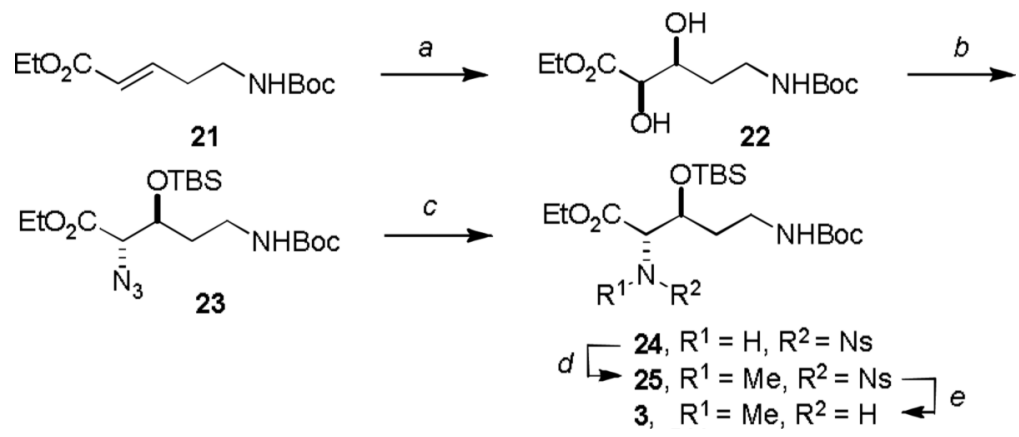

Scheme 4.

Synthesis of the $\beta$-hydroxyornithine subunit. a) AD mix $\alpha, 90 \%$; b) $1 . \mathrm{SOCl}_{2}, \mathrm{Et}_{3} \mathrm{~N} ; 2 . \mathrm{NaN}_{3}$, DMF, $55^{\circ} \mathrm{C}$; 3. TBSOTf, 2-6-lutidine, $\mathrm{CH}_{2} \mathrm{Cl}_{2}, 80 \%$ (3 steps); c) 1. $\mathrm{Pd} / \mathrm{C}, \mathrm{H}_{2}$, EtOAc; 2. NsCl, $i$ - $\mathrm{Pr}_{2} \mathrm{NEt}, \mathrm{CH}_{2} \mathrm{Cl}_{2}, 94 \%$ (2 steps); d) $\mathrm{MeOH}, \mathrm{Ph}_{3} \mathrm{P}$, DEAD, THF; e) $\mathrm{PhSH}, \mathrm{K}_{2} \mathrm{CO}_{3}, \mathrm{DMF}, 82 \%$ (2 steps). Boc=tert-butoxycarbonyl, DEAD=diethyl azodicarboxylate, $\mathrm{DMF}=\mathrm{N}, \mathrm{N}$ dimethylformamide, $\mathrm{Ns}=O$-nitrophenyl sulfonyl, TBS=tert-butyldimethylsilyl. 


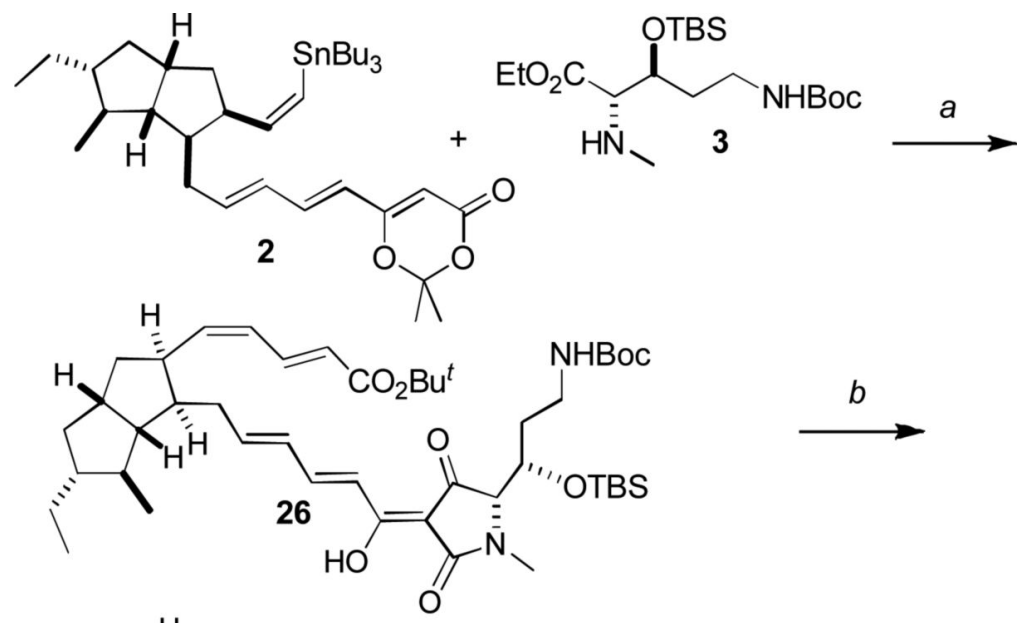

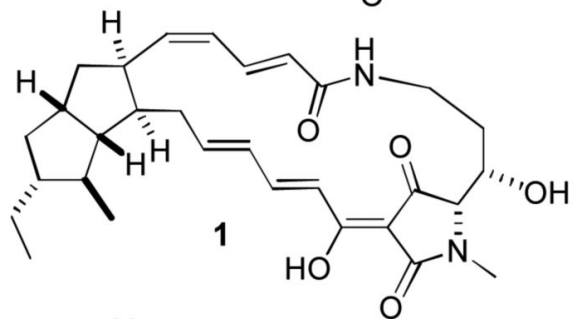

aburatubolactam $A$

Scheme 5.

Completion of the synthesis. a) 1 . $\mathrm{PhMe}, 110{ }^{\circ} \mathrm{C}$; 2 . tert-butyl- $\beta$-iodoacrylate, $\mathrm{Pd}_{2}(\mathrm{dba})_{3}$, $\mathrm{Ph}_{3} \mathrm{As}, \mathrm{NMP} ; 3$. NaOMe, $\mathrm{MeOH}, 50 \%$ (3 steps); b) 1. TFA, $\mathrm{CH}_{2} \mathrm{Cl}_{2} ; 2$. DEPC, Et 3 N, DMF, rt; 3) $\mathrm{HF}, \mathrm{MeCN}, 46 \%$ (3 steps). NMP=N-methylpyrrolidinone, TFA=trifluoroacetic acid, $\mathrm{DEPC}=$ diethylphosphoryl cyanide, $\mathrm{DMF}=N, N$-dimethylformamide. 